\title{
The role of higher education in the digital economy development
}

\section{O papel da educação superior em língua inglesa no desenvolvimento da economia digital}

\section{El papel de la educación superior en lengua inglesa en el desarrollo de la economía digital}

\author{
Nataliia Kholiavko1 ${ }^{\text {iD }}$, Olha Popelo1 ${ }^{\text {iD }}$, Anatolii Melnychenko² iD, \\ Marta Derhaliuk2 iD, Liudmyla Grynevych ${ }^{3}$ iD \\ ${ }^{1}$ Chernihiv Polytechnic National University, Chernihiv, Ukraine. \\ ${ }^{2}$ National Technical University of Ukraine "Igor Sikorsky Kyiv Polytechnic Institute”, Kyiv, Ukraine. \\ ${ }^{3}$ Simon Kuznets Kharkiv National University of Economics, Kharkiv, Ukraine. \\ Corresponding author: \\ Olha Popelo \\ Email: popelo.olha@gmail.com
}

How to cite: Kholiavko, N., Popelo, O., Melnychenko, A., Derhaliuk, M., \& Grynevych, L. (2022). The role of higher education in the digital economy development. Revista Tempos e Espaços em Educação, 15(34), e16773.

http://dx.doi.org/10.20952/revtee.v15i34.16773

\begin{abstract}
The purpose of the article is to study the role of higher education in the development of the digital economy. To achieve the goal, the authors used the methods of analysis and synthesis; content analysis; scientific abstraction and systematization. The authors conclude that promising areas for strengthening the positive impact of higher education on the development of the digital economy are: improving dual education to provide the national economy with personnel capable of innovative thinking and action; introduction of lifelong learning programs, short-term highly specialized training programs; formation of information and innovation cultures in society; generation of innovative ideas and their commercialization in the real sector of the economy; supporting the development of innovation and information infrastructures; support for youth innovation projects; increasing the level of the English language proficiency in order to expand the opportunities for participation of universities in international research and educational projects
\end{abstract} Keywords: Digital economy. Digitalization. Dual education. Higher education.

\section{RESUMO}

O objetivo do artigo é estudar o papel do ensino superior no desenvolvimento da economia digital. Para atingir o objetivo, os autores utilizaram os métodos de análise e síntese; análise de conteúdo; abstração e sistematização científica. Os autores concluem que as áreas promissoras para fortalecer o impacto positivo do ensino superior no desenvolvimento da economia digital são: melhorar a 
educação dual para dotar a economia nacional de pessoal capaz de pensar e agir inovadores; introdução de programas de aprendizagem ao longo da vida, programas de treinamento altamente especializados de curto prazo; formação de culturas de informação e inovação na sociedade; geração de ideias inovadoras e sua comercialização no setor real da economia; apoiar o desenvolvimento de infraestruturas de inovação e informação; apoio a projetos de inovação juvenil; aumentar o nível de proficiência da língua inglesa, a fim de expandir as oportunidades de participação das universidades em projetos internacionais de pesquisa e educação.

Palavras-chave: Digitalização. Economia digital. Educação dual. Ensino superior. Ensino superior.

\section{RESUMEN}

El propósito del artículo es estudiar el papel de la educación superior en lengua inglesa en el desarrollo de la economía digital. Para lograr el objetivo, los autores utilizaron los métodos de análisis y síntesis; análisis de contenido; abstracción científica y sistematización. Los autores concluyen que las áreas prometedoras para fortalecer el impacto positivo de la educación superior en el desarrollo de la economía digital son: mejorar la educación dual para proporcionar a la economía nacional personal capaz de pensar y actuar de manera innovadora; introducción de programas de aprendizaje permanente, programas de formación de corta duración altamente especializados; formación de culturas de información e innovación en la sociedad; generación de ideas innovadoras y su comercialización en el sector real de la economía; apoyar el desarrollo de infraestructuras de información e innovación; apoyo a proyectos de innovación juvenil; aumentar el nivel de dominio del idioma inglés para ampliar las oportunidades de participación de las universidades en proyectos internacionales de investigación y educación.

Palabras clave: Digitalización. Economía digital. Educación dual. Educación superior.

\section{INTRODUCTION}

Activation of the development of the national economy on the basis of sustainability and information implies the need to take into account a set of dynamic factors of exogenous and endogenous environment, a prominent place among which are scientific, technical and informational factors. Given the intensification of globalization, the above causes the national economy to approach one of the defining global trends of developed countries - the formation of the digital economy, accompanied by the transformation of social relations and modification of the role of fundamental and applied knowledge and information resources. Moreover, the specificity of the latter is manifested in the active penetration into socio-economic relations at different levels of their implementation, as well as in the emergence of synergistic effects from the interaction of actors involved, features of interaction and interaction require in-depth further identification of areas for improving the system of state regulation in the transition to a digital economy.

The effectiveness of the transition of the national economy to the principles of information largely depends on the availability of a national strategic vision, political will, financial resources. Such a transition will mean technological modernization of the real sector of the economy and will be accompanied by structural and functional changes at both the macro- (national economy), meso(regional socio-economic systems) and at the macro (economic entities) levels; will take place against the background of objective facts of cyclical economy, dynamic scientific and technological development, exacerbation of political and military threats in the current economic and social problems. The necessary transformations should be based on the generation of new knowledge and ideas, the production of science-intensive products, the commercialization of scientific and technical developments and the widespread use in practice of modern information resources. In other words, we are talking about a progressive transition to the digital economy - "that part of basic economics that studies economic laws and patterns in the field of production, generation of scientific and technical information and scientific knowledge" (Shkarlet, 2015). 
The aim of the article is to study the role of the higher education system in ensuring the formation and development of the digital economy. The main objectives of the article include the following: identification of modern factors in the development of the digital economy; research of scientific approaches to studying the role of education in the development of society and economy; analysis of the contribution of higher education institutions to the development of the digital economy through the prism of their functions; revealing the importance of dual education in the processes of digital economy development.

\section{LITERATURE REVIEW}

Many research papers are devoted to the development of higher education, as well as the processes of digitalization: Bazhenkov (2021); Bogomolova (2021); Cosmulese (2019); Dubyna (2021); Fadeeva (2021); Ivanova (2016); Kovalska (2021); Kravchenko (2021); Lazarenko (2020); Makashina (2021); Mammadov (2019); Samoilovych (2021); Sandal (2020); Selamovski (2021); Shkarlet (2020); Tulchynska (2021) and others.

In response to the trends of digital transformation of the economy, higher education is also being digitalized, which is reflected in a number of scientific publications. In particular, Fadeeva (2021) focuses on describing digital tutoring support technologies for students learning a foreign language online as part of a distance retraining program. Shulga et al. (2021) analyzed the language and cognitive barriers faced by Internet technology users; researchers have concluded that one of the most common practices, along with banking and e-government, is online education. Mammadov Nasiraga Shakhmurad oglu et al. (2019) investigated the features of the development of foreign language communicative competencies of university students in the modern conditions of internationalization and globalization of national higher education systems. Some aspects of the development of foreign language communicative competence of students in the extracurricular work of universities are disclosed in the article of Sandal et al. (2020).

There are a lot of publications, which are at the intersection of sciences, ie those that combine linguistic elements of the study of economic phenomena and processes. For example, the article of Makashina et al. (2021) is devoted to the study of the etymological concept of the definitive approach to the study of economic implementation. In the work of Selamovski et al. (2021) reveals the features of strategic linguistic definition and political science discussion to assess tax efficiency and impact on the economy. In the article of Bogomolova et al. (2021) are proposed the modern digital tools and linguistic-cultural definitions of countries for mass recruitment for large retailers. At the same time, the authors of these publications do not pay enough attention to the current aspects of digitalization of national economies, which are the main focus of our paper. Despite the existence of a thorough scientific work of researchers, the question of determining the role and priority areas of activating the influence of the higher education on the processes of formation of the digital economy require in-depth research.

\section{METHODOLOGY}

The following methods were used during the study:

- analysis and synthesis - to determine the degree of development of the research problem;

- content analysis - to study scientific approaches to determining the role of education in the development of society and economy;

- scientific abstraction and systematization - to generalize the processed scientific materials, and formulate the authors' position on promising areas of strengthening the impact of higher education on the development of the digital economy. 


\section{RESULTS}

Reconfiguration of the national economy for development on the basis of information will allow to intensify integration processes due to Ukraine's approach to global trends of world development. In the conditions of resource constraints, aggravation of foreign economic and security threats, internal political and socio-economic risks, the key promising driving force on the path of transformation of the macroeconomic model of development is knowledge and information. That is, securing a competitive position in the world market and moving away from the position of the raw material appendage requires a transition to fundamentally new principles of operation: active development of scientific and technical information in production processes, automation, informatization of industrial production, focusing on economic support. commercialization of materialized and non-materialized knowledge, conducting economic activity in accordance with the principles of sustainable development, as well as maintaining the positive dynamics of the trend of deployment of integration processes in Ukraine. Achieving these goals is possible on the basis of development of effective, synchronized cooperation between the sectors of government, entrepreneurship, higher education and the public with the optimal balance of their interests, balanced government regulation, testing of best world practices with their adaptation to Ukrainian realities on the principles of scientific validity.

The above logically causes a change in the methods of organizing and conducting business. It should be emphasized that in the twentieth century it is impossible to ensure the achievement and long-term maintenance of high competitive positions on the basis of standard, traditional, ordinary approaches to doing business. The leaders in the market in modern conditions are enterprises capable of generating innovations, actively implementing the innovative technologies and effectively operating with information resources. The defining characteristic of such enterprises is their ability to self-organization and self-development. In conditions of fierce competition, innovation-active enterprises, with creative ideas and non-standard decision-making, have an advantage in the market competition.

The economic system is undergoing significant transformations under the influence of information and communication technologies. The implementation of modern technologies allows to optimize and accelerate the flow of business processes, thus reducing the period of production and delivery of goods to consumers. The technological lag of Ukrainian producers in the new economic conditions causes a deepening of the technological gap between the national economy and the leading countries - world innovation leaders.

Moreover, innovative information and communication technologies are becoming an integral part of business. This is reflected in the unprecedented growth of services, large-scale development of e-business, the emergence of so-called virtual enterprises. In the higher education sector, this is reflected in the spread of dual education; in the government sector - in the organization of electronic document management, the emergence of the model of "electronic government" (e-government).

Among the important factors are cultural, the essence of which is the development of innovation and information culture in society as a basis for intensifying the processes of development of the digital economy. This will allow citizens and businesses to become aware of the importance of information resources and innovation in ensuring economic growth.

Regulatory factors include, on the one hand, a set of regulations in the field of protection of intellectual property rights, and carrying of educational, research, technical and innovation activities. On the other hand, this group of factors includes the impact of measures to minimize bureaucratic procedures, to ensure compliance with current legislation and ensure its updating in accordance with changes in the external environment, synchronization with EU standards.

The financial factors that are most painful for most developing countries should be singled out. This also applies to the current situation in Ukraine - political, economic instability, resource 
constraints, difficult geopolitical situation. The underdevelopment of financial factors leads to the inability of economic entities to regularly update the material and technical base, to introduce technological innovations, to produce innovative products.

A partial solution to the above problems is possible with the development of the coordination factor. Establishing intersectoral cooperation in the context of the digital economy is of particular importance. Because the operational mastery of business innovations requires close business contacts with knowledge-generating organizations (universities, research institutes) with balanced government regulation and incentives. Coordinating the interests and the activities of actors in different sectors of the national economy allows them to combine their intellectual, financial, logistical potential to achieve the goals of innovative development and synergies from cooperation. In this context, it is necessary to mention the problem of underdevelopment in Ukraine of mechanisms of state legal and financial regulation and stimulation of cooperation of subjects of higher education and entrepreneurship sectors in the scientific, technical and innovative spheres.

In addition to the above, the processes of development of the digital economy are determined by innovation factors (Fig. 1), which mean: innovative capacity, receptivity and openness of economic entities to innovation, the ability to bring ideas to the stage of commercially attractive innovation, etc. At the same time, the ability of economic entities to create flexible organizational structures and ensure their innovation is important. This will allow the development of effective mechanisms for cross-sectoral cooperation in the fields of education, science and innovation, as well as contribute to the higher efficiency of dual education programs implemented by the joint efforts of universities and business.

Figure 1. Components of the digital economy development.

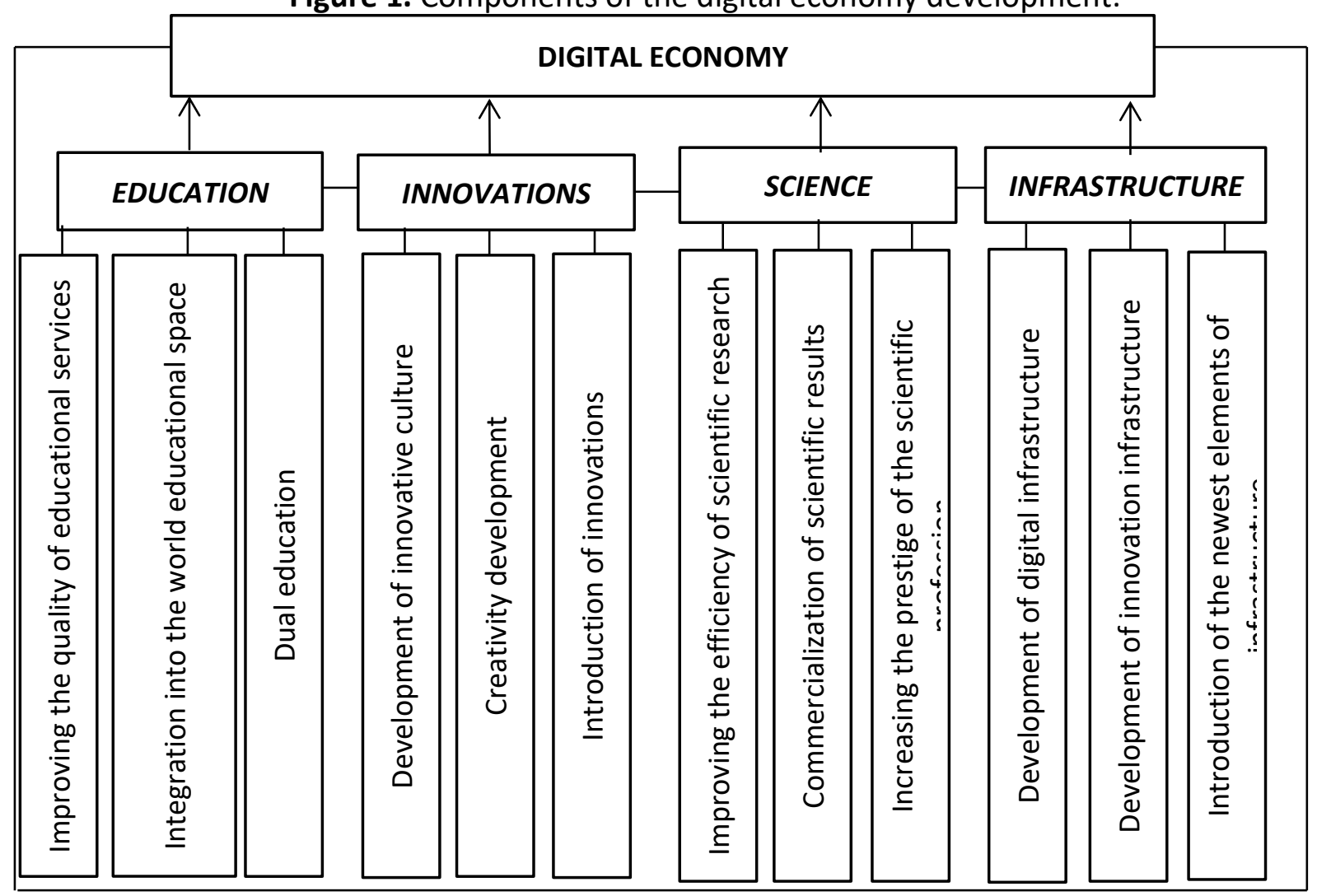

The factor of intellectualization needs complex consideration (Fig. 2). First, in the perspective of increasing the level of education of the population, indicators of education coverage, increasing the share of the population with higher education, as well as mass education, loss of elite status by higher vocational education, accompanied by increased access to educational services. Second, in 
the perspective of a qualitative change in the requirements of employers to the qualified and professional characteristics of employees - with an emphasis on creativity, level of technology, readiness to master and produce innovations. Third, through the prism of modernizing the higher education system to ensure the applicability of its results to the demands of the digital economy. Fourth, through the prism of scientific, technical and research activities carried out by universities, the results of basic and applied research lay the foundations for the sustainable development of the digital economy.

Figure 2. Three-component model of the influence of the higher education system on the

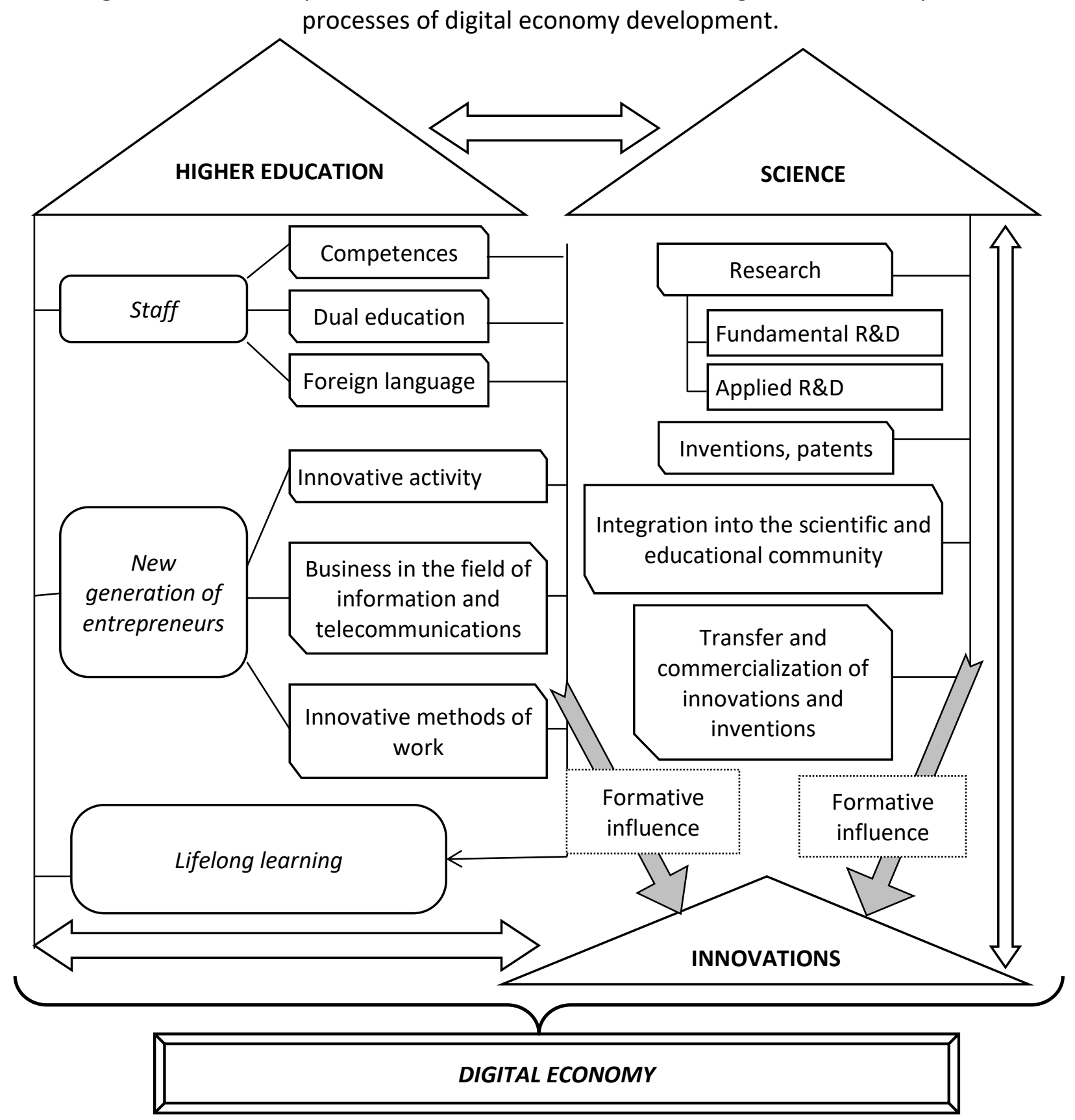

In the studied context, the need for in-depth study of the potential of the higher education in the formation of the digital economy in Ukraine is highlighted. Because educational institutions provide training of highly qualified specialists in accordance with the requests of employers, generate innovations and ensure their transfer to the real sector of the economy. Strengthening the 
constructive influence of the higher education on the processes of the digital economy development requires the transformation of universities into powerful centers of innovation and transfer. Higher education institutions should become drivers of change, taking into account the specifics of their activities in accordance with the traditional and modern activities and functions. In particular, the traditional functions - educational, methodological, and research ones - should be as adaptive as possible to current and future demands of society. It is expedient for universities to intensify their own activities in the direction of organizing the effective implementation of modern functions innovative, entrepreneurial, international ones with a focus on current trends and challenges of the globalized world. It is important to understand that in the conditions of rapid globalization the requirements to competencies and knowledge of university graduates are transformed. Ensuring high competitiveness of graduates in the international labor market requires the implementation of higher education institutions a comprehensive approach to teaching the English language. This approach should include both: in-depth study of the English language by students, and teaching of specialized disciplines in English.

To ensure the completeness of our study, key scientific views on the role of education in the development of society and the national economy are systematized in table 1 . From the data of table 1 shows that both the classics of economics and modern scientists unequivocally state the significant impact of knowledge and education on the dynamics and effectiveness of economic processes, labor productivity, incomes, and economic growth in general.

Table 1. Evolution of theoretical views on the role of education in the development of society.

\begin{tabular}{|c|c|}
\hline Scientist & The content of views \\
\hline W. Petty (1997) & $\begin{array}{l}\text { Human knowledge and skills are considered as a component of the wealth of } \\
\text { the individual and society }\end{array}$ \\
\hline A. Smith (1962) & $\begin{array}{l}\text { It is noted that the cost of education of workers contributes to increased } \\
\text { productivity and recouped by increasing profits }\end{array}$ \\
\hline J. Mill & $\begin{array}{l}\text { considered in the context of analyzing the causes of } \\
\text { els }\end{array}$ \\
\hline $\begin{array}{l}\text { K. Marx, } \\
\text { F. Engels (1965) }\end{array}$ & $\begin{array}{l}\text { Labor is divided into simple and skilled, which has a higher cost and creates } \\
\text { more products per unit time }\end{array}$ \\
\hline 3) & $\begin{array}{l}\text { The conditions of economic growth include the development of human } \\
\text { abilities; the necessity of state intervention in the sphere of education is } \\
\text { substantiated }\end{array}$ \\
\hline .1 & $\begin{array}{l}\text { It is proved that knowledge is a part of capital as a factor of production; } \\
\text { increasing the level of education of the employee causes an increase in } \\
\text { productivity of himself and his colleagues. General and specific abilities of the } \\
\text { employee are singled out }\end{array}$ \\
\hline & \\
\hline J. G & $\begin{array}{l}\text { In the structure of industrial society } t \\
\text { people with special knowledge and abi } \\
\text { corporations and determine the goals }\end{array}$ \\
\hline S. S & $\begin{array}{l}\text { The economic efficiency of compulsory education is calculated: literacy helps } \\
\text { to increase labor productivity by about } 30 \% \text {; training of illiterate workers at } \\
\text { the plant - not more than } 16 \% \text {; schooling allows } 2.6 \text { times more training } \\
\text { compared to the same period of study at the enterprise. The profitability of } \\
\text { educational institutions of different levels is calculated }\end{array}$ \\
\hline $\begin{array}{l}\text { Zhamin V.A., } \\
\text { Egiazaryan G.A. } \\
\text { (1968) }\end{array}$ & $\begin{array}{l}\text { Approaches to calculating the level of wages - with increasing rates from the } \\
\text { level of the worker of the first category depending on the level of } \\
\text { qualification are studied }\end{array}$ \\
\hline
\end{tabular}


S.L. Kostanyan, E.M. The calculation of the level of wages is based on the actual social costs of Residents (1986) training employees. The dependence of the growth of national income on education and qualification of personnel is proved; calculated return on investment in the development of education (growth of national income by $20 \%$ in the period from 1970 to 1979)

T. Schultz (1961) The economic efficiency of investment in human capital is studied; comparison of costs and return on investment in education; the dependence of wages on the level of education is substantiated; a monetary approach to the analysis of education has been applied

J. Stiglitz (1987, The selective function of education, which is to determine the abilities of the 1997)

E. Denison (1971) individual, to identify the most productive workers

The contribution of education to economic growth has been calculated (on the example of the USA in comparison with the countries of Western Europe)

R. Lucas (1988, 1994)

Recognizing the asymmetry, inaccuracy of information and inequality of access to education, the expediency of state intervention is substantiated; the introduction of educational loans is proposed. Examples of information asymmetry are given: on the selection of students; on the selection of training programs; on vocational training in enterprises

P. Drucker (1996) The special state policy in the field of education is substantiated; it is proved that knowledge is a source of wealth. The necessity of transformations in the education system as a reaction to the requirements of the knowledge economy is determined

K. Ohmae (1982) The connection between education and management style in business has been studied

M. Porter (1990) The role of education in ensuring the competitiveness of the country and enterprises is shown. Emphasis was placed on the need to establish high educational standards, bring education closer to practice, increase private investment in education, etc.

J. Naisbitt, P. Investments in human capital and education are considered as a source of Aborden (1990) formation of future competitive advantages of the country at the international level

E. Toffler (1990) Knowledge as the main component of post-industrial society, the importance of which will continue to grow, is analyzed; noted the importance of modernizing education

T. Gaudin (1990) The state of education is analyzed, the decrease in the efficiency of education is noted, the conclusion about the need for transformation in education, the importance of lifelong learning is made

A. Gorz (1988) Education is considered as an effective means of social integration in the long run

R. Reich (1991) It is determined that the welfare of the people depends on the knowledge and skills of citizens, which form the basis of competitiveness

M.M. Kryvytskyi Aspects of the organization of economic higher education are studied (1926)

Source: compiled by the authors on the basis of Kalieniuk (2012).

The national higher education system is a central element in the development of the information society and the development of the digital economy. In our opinion, it is expedient to study the peculiarities of its functioning and its significance in the development of the digital economy through the prism of the activities and functions of higher education institutions. 
Educational institutions determine the development of the digital economy not only through educational activities (training, retraining, in-service training, lifelong learning, dual education), but also through the implementation of research function combined with innovation activity. The contribution of the higher education system in this perspective is as follows:

- the results of fundamental research lay the foundation of technological breakthrough, the basis of innovative leadership of enterprises in the global market;

- the results of applied research can effectively solve the current problems of economic entities;

- the universities' research activity contribute to the diffusion of knowledge and information, popularization of science and its potential in society and the business environment;

- patenting of inventions and developments provides protection and legally correct transfer of intellectual property rights;

- bringing the results of scientific research to the phase of innovation, ie ensuring their practical and commercial value.

Research and innovation activities of universities in a market economy creates opportunities for them to perform their entrepreneurial function. The development of universities' entrepreneurial activity actively contributes to the convergence of the higher education system with the entrepreneurial sector, as it involves the search for common interests, consolidation of potentials and coordination of partners' activities. The success of the implementation of individual research projects implemented by higher education institutions and funded by business structures, creates the preconditions for the development of their long-term mutually beneficial cooperation.

Commercialization of research results ensures the movement of innovative developments, the latest technology and modern information and communication technologies in the real sector of the national economy. Their introduction into the practice of management helps to optimize the cost structure of the enterprise; means the transition to functioning on a qualitatively new basis of innovation and information; allows to accelerate processes of acceptance of administrative decisions thanks to use of possibilities of information and communication technologies; leads to a reduction of the production cycle and the period of meeting the needs of end users by constantly increasing the degree of informatization, automation, robotization of production processes, etc. Thus, it can be noted that the commercialization of university research results causes: at the microeconomic level increasing the degree of innovation activity and competitiveness of enterprises; at the macroeconomic level - promoting the digital economy.

In the analyzed context, it is expedient to emphasize the important role of universities in promoting innovative youth entrepreneurship. This includes both educational activities (in the course of dual education) and the establishment of technology parks, innovation centers, research parks, business incubators, consulting centers for start-ups, etc. The universities could propose the favorable conditions for starting an innovative, usually high-risk business. Higher education institutions can also be co-founders of small enterprises focused on the generation, development and commercialization of innovations. This kind of structure is the link between university education (economic knowledge), science (research results) and business (practical implementation). Significant commercial attractiveness is marked by engineering developments, the latest technical devices, computer, digital, information, communication technologies; there is a growing demand for biotechnology, nanotechnology, medical inventions.

Establishing effective communications between the higher education and entrepreneurship means expanding, simplifying and accelerating the access of innovatively active businesses to modern scientific developments, as well as deepens the opportunities for improving dual education. Moreover, the trends of globalization and internationalization of higher education lead to the opening of access to the world's leading scientific achievements and provides the opportunity for international transfer of technology and information. In our opinion, it is worth emphasizing that 
the English language in the current context of globalization play a key role not only in the educational activities of universities, but also in the implementation of their research functions. Perfect knowledge of the English language allows university scientists to read scientific publications in the original, as well as to ensure greater readability of their own publications. In addition, the English language is a necessary element of successful participation in international research and educational projects. This will ensure the prompt and easier integration of the national higher education system into the world scientific and educational area.

Systematizing, the impact of higher education on the development of the digital economy is manifested in:

- development and continuous improvement of dual education in order to provide the national economy with personnel capable of thinking, acting and acting creatively; provision of high quality educational services;

- introduction of the principles of lifelong learning as a basis for professional selfdevelopment and competitiveness in the labor market;

- dissemination of short-term highly specialized training programs aimed at the formation of specific professional competencies, which can be implemented on the basis of modern system of dual education;

- generation of innovative ideas, knowledge, information, technologies;

- commercialization of research results; transfer of knowledge and information;

- development of information culture in society;

- diffusion of innovations as a result of research of higher education institutions;

- development of innovation culture, accompanied by an increase in the susceptibility of the ability to quickly master innovations, as well as the tendency to generate them;

- partnership in the establishment of small enterprises, which activity is focused at the commercialization of innovations;

- providing consulting, expert, engineering and other services to innovation-oriented enterprises;

- joint initiation, development and implementation of scientific and educational projects;

- creation and support of research parks, technology parks, business incubators;

- supporting the development of innovation and information infrastructure;

- expanding access of enterprises to promising scientific developments and innovations;

- support of youth innovative projects;

- providing opportunities for partnership within the projects funded by international organizations or foundations;

- development of technologies for creating a single information area and expanding access of economic entities to its resources, etc.

The above is grouped and represented by the data of Fig. 3. In our opinion, it is useful to influence of the higher education system on the processes of development of the digital economy through the prism of the universities' educational, research and innovation activities.

The potential available in Ukraine, with its proper support and stimulation of development, is quite capable of laying the foundations and creating the preconditions for the development of a digital economy. It is especially important for the national economy of the country to increase the level of motivation of business entities to carry out innovative activities in conditions of limited funding for education, science and innovation. Moreover, first of all it is expedient to focus on determining the priority of innovative ideas in economic development, decent funding of research activities of fundamental and applied research, to increase the use of modern information and communication technologies in the educational process; to increase the share of science-intensive products in GDP; to develop new sectors of the national economy (for example, related to the development of biotechnology, information technology, nanotechnology, etc.). Strategic 
orientation should be presented not only in order to achieve global leadership, but also to guarantee the appropriate pace of socio-economic development and improve the quality of life.

Figure 3. Directions of influence of higher education institutions on the processes of digital economy development by the main types of their activity.

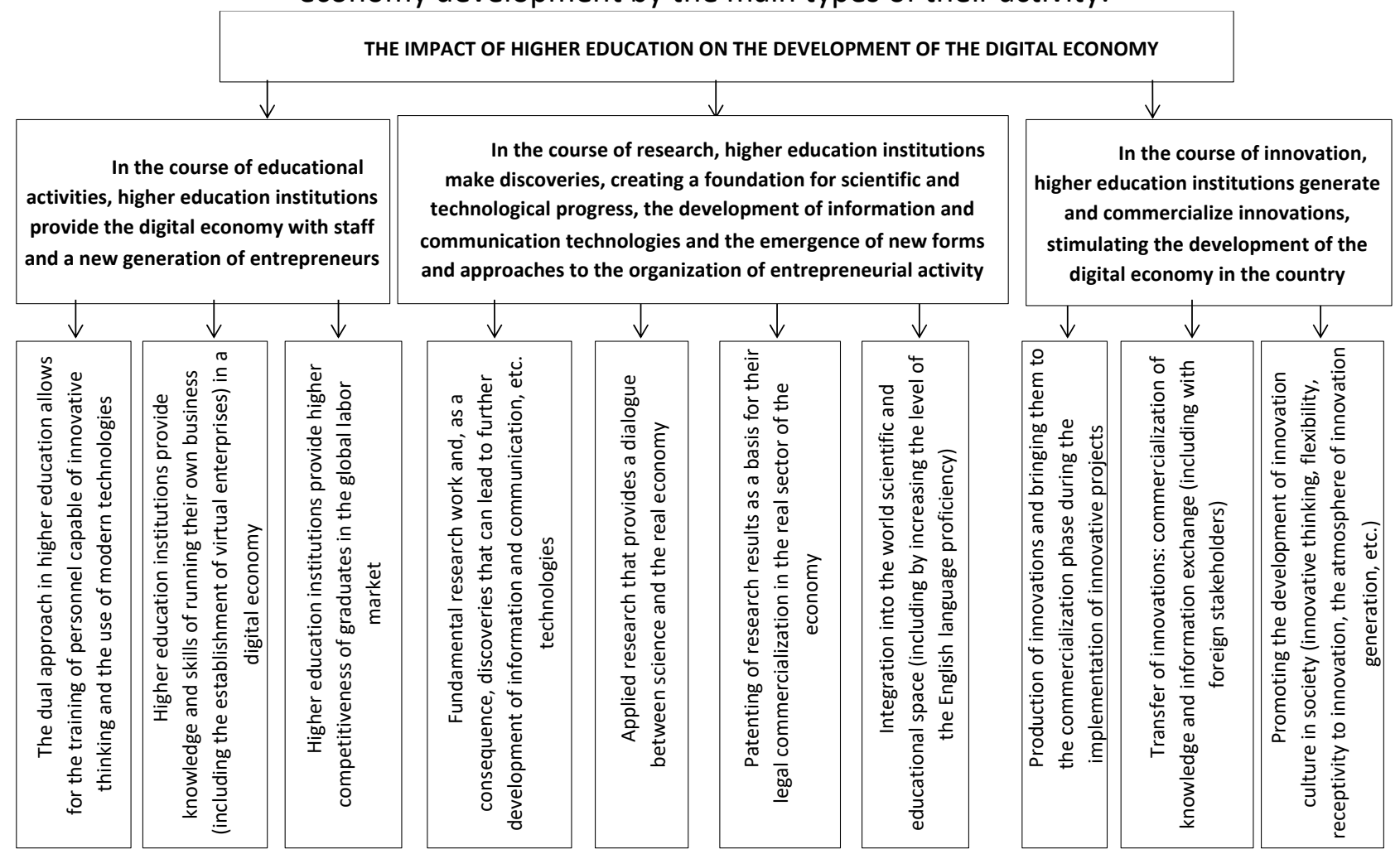

\section{CONCLUSION}

Thus, the strategic basis of the transition to the digital economy is a strong intellectual potential of Ukraine, which is formed and intensified primarily by higher education institutions. The exceptional importance of higher education in the processes of development of the digital economy is to strengthen the intellectual potential, ensuring the development of human resources. In addition, the efforts of universities ensure the renewal of information and methodological and organizational base, the development of management capacity, as well as, most importantly in the analyzed context - strengthening the scientific potential of the country. Consolidation of domestic potential will allow optimizing measures to implement the modern macroeconomic digital model in Ukraine.

National priorities should focus on aspects of development of knowledge-intensive sectors of the national economy, increasing the pace of implementation of information and communication technologies in all areas of activity, ensuring innovative development, activation of the knowledge market and digital industry. Research demonstrates the existence of common features of the digital economy, which are global in nature and are typical for different countries. In addition, there are some national and regional differences in the implementation of the digital economy, which often have a strong impact and lead to certain differences in strategic approaches and the actual state of economies' digitalization. In addition to the above, national and regional differences are manifested in different rates, duration, degree of intensity and degree of formalization of the processes of implementation of elements of the digital economy. The effective strategic approaches to the development of the digital economy in Ukraine requires a thorough study of leading world experience in order to identify best practices for their further implementation in the country with adaptation to domestic socio-economic realities, national economic system and regional specifics. 
Authors' Contributions: Kholiavko, N.: conception and design, acquisition of data, analysis and interpretation of data, drafting the article, critical review of important intellectual content; Popelo, O.: conception and design, acquisition of data, analysis and interpretation of data, drafting the article, critical review of important intellectual content; Melnychenko, A.: conception and design, acquisition of data, analysis and interpretation of data, drafting the article, critical review of important intellectual content; Derhaliuk, M.: conception and design, acquisition of data, analysis and interpretation of data, drafting the article, critical review of important intellectual content; Grynevych, L.: conception and design, acquisition of data, analysis and interpretation of data, drafting the article, critical review of important intellectual content. The author has read and approved the final version of the manuscript.

Ethics Approval: Not applicable.

Acknowledgments: This research is carried out with in the frame work of the scientific project "Integrated Model of Competitive Higher Education in Ukraine under the Quadruple Helix Concept" with the support of the Ministry of Education and Science of Ukraine (state registration number 0117U007258).

\section{REFERENCES}

Bogomolova, I., Krivenko, E., Trineeva, L., Malitskaya, V., Volkova, N. (2021). Digital Instruments And Country Linguacultural Definitions Of Mass Recruitment For Large Retailers. ALRJournal, 5(4), 191-200.

Cosmulese, C.G., Grosu, V., Hlaciuc, E., Zhavoronok, A. (2019). The Influences of the Digital Revolution on the Educational System of the EU Countries. Marketing and Management of Innovations, 3, 242-254.

http://doi.org/10.21272/mmi.2019.3-18

Denison, E. (1971). A Study of Differences in Economic Growth. Moscow: Progress.

Drucker, P. (1996). The new realities. Oxford.

Fadeeva, V. (2021). Tutor Support in the Process of Language Education Digitalization: A Case Study of University Distance Language Learning. ALRJournal, 5(3), 70-75.

Galbraith, J. (1969). New Industrial Society (pp. 38-39).

Gaudin, T. (Ed.) (1990). 2100: recit du travail. Paris, Edition Payot.

Gorz, A. (1988). Metamorphose du travail. Paris, Editions Galilee.

Ivanova, N., Butko, M. (2016). The Modern Trends of Infrastructure Development. Baltic Journal of Economic Studies, 2(3), 37-41.

Kalenyuk, I.S., Kuklin, O.V. (2012). Development of higher education and economics of knowledge. Kyiv: Knowledge.

Keynes, J. M. (1993). General theory of employment, interest and money. [trans. from English]. Moscow: Eksmo.

Kholiavko, N., Djakona, A., Dubyna, M., Zhavoronok, A., \& Lavrov, R. (2020). The higher education adaptability to the digital economy. Bulletin of the National Academy of Sciences of the Republic of Kazakhstan, 4(386), 294-306.

https://doi.org/10.32014/2020.2518-1467.130

Kholiavko, N., Popelo, O., Tulchynska, S. (2021). Priority Directions of Increasing the Adaptivity of Universities to the Conditions of the Digital Economy. Revista Tempos E Espaços Em Educação, 14(33), e16383.

https://doi.org/10.20952/revtee.v14i33.16383

Kholiavko, N., Popelo, O., Bazhenkov, I., Shaposhnykova, I., Sheremet, O. (2021). Information and communication technologies as a tool of strategy for ensuring the higher education adaptation to the digital economy challenge. IJCSNS International Journal of Computer Science and Network Security, 21(8), p. 187-195.

https://doi.org/10.22937/IJCSNS.2021.21.8.25

Kostanyan, S.L. (Ed.). (1986). Economics of public education. (2nd ed.). Moscow.

Kryvytskyi, M.M. (1926). Organization of the Victory of Political Economy in KhINO. Notes of Kharkiv. in-tu nar. insight into im. O.O. Potennia (vol. 1). Kharkiv.

Lazarenko, I., Saloid, S., Tulchynska, S., Kyrychenko, S., Tulchinskiy, R. (2020). Necessity of implementating data science course in economics curricula. Information technologies and teaching aids, 4(78), 132-144.

https://doi.org/10.33407/itlt.v78i4.3505

Lukas, R.E. (1988). On the mechanics of economic development. Journal of Monetary Economics, 22. 
Lukas, R.E. (1994). The impact of structural adjustment of training needs. International Labour Review, 133(5-6), 677694.

Makashina, O., Alandarov, R., Lutoshkina, E., Alymova, O., Akhmadeev, R., Avvakumova, I. (2021). Sezs: Exploring the Etymological Concept of a Definitional Approach to Study of Economic Implementation. ALRJournal, 5(4), $228-236$.

Mammadov, Nasiraga Shakhmurad oglu, Sokolova, S., Kholiavko, N. (2019). Development Of Students' Foreign Language Communicative Competence In Context Of Internationalisation And Informatisation Of Higher Education. Advanced Education, Special Issue 11, 22-29.

Marshall, A. (1983). Principles of Political Economy. Moscow: Progress.

Marx, K., Engels, F. (1965). Capital (vol. 1). In Works (vol. 23, pp. 208-209).

Mill, J.S. (1980). Fundamentals of Political Economy. Moscow: Progress.

Naisbitt, J., Aburdene, P. (1990). Megatrends 2000. New York, W. Moore and Company Inc.

Newman, J.H. (1887). The Idea of University defined and illustrated. London: Longmans, Green\&Co.

Note on the Kiev Commercial Institute (1909).

Ohmae, K. (1982). The mind of the strategist: the art of Japanese business. New York, McGraw-Hill.

Petty, W. (1997). Treatise on Taxes and Fees. Verbum sapienti. Miscellaneous about money. Moscow: Os-89.

Porev, S.M. (2012). University and Science. Epistemology, methodology and pedagogy of knowledge. Kyiv: Khimjest.

Porter, M. (1990). The competitive advantage of nations. New York, The Free Press.

Reich, R. (1991). The work of nations. New York, Alfred A. Knopt.

Samoilovych, A., Garafonova, O., Popelo, O., Marhasova, V., \& Lazarenko, Yu. (2021). World experience and ukrainian realities of digital transformation of regions in the context of the information economy development. Financial and credit activity: problems of theory and practice, (3(38)), 316-325. https://doi.org/10.18371/fcaptp.v3i38.237462

Sandal, Ja.-U., Detsiuk, T., Kholiavko, N. (2020). Developing foreign language communicative competence of engineering students within university extracurricular activities. Advanced education, 14, 19-28.

Saprykin, D.L. (n.d.). The Concept of Education and Science in The Idea of Moscow the University by John Henry Newman. http://www.ihst.ru/files/saprykin/Newman.pdf

Schultz, T. (1961). Investment in human capital. American Economic review, 51(1).

Selamovski, F., Sobenina, S., Ponomareva, N., Golubtsova, E. (2021). Strategic Linguistic Definitions And Politological Discussions To The Assessment Of Tax Efficiency And Impact On The Economy. ALRJournal, 5(4), $219-227$.

Shkarlet, S.M. (2014). Information economy as a basis of socio-economic regeneration of Ukraine. Ukraine economy, (11(636)), 51-60.

Shkarlet, S.M. (2015). Technology of management of processes of formation and introduction of system-universal determinants of development of economy of information type. Scientific journal "Economy of Ukraine", (7(644)), 2940.

Shulga, T., Charikova, I., Smirnov, V., Zharkova, A., Yarygina, N., Kanyaeva, O., Muradova, I. (2021). Digital Transformation, Communication Culture, Language and Cognitive Barriers by Internet Users Views. ALRJournal, 5(6), 195-200.

Smith, A. (1962). A Study on the Nature and Causes of the Wealth of Nations. Moscow: Sotsekgiz.

Stiglitz, J. (1987). Learning to learn, localized learning and technological progress. Economic performance and technological change. Centre for economic Policy Research, Cambridge, Mass., Cambridge University Press.

Stiglitz, J.Yu. (1997). Public Sector Economics. Moscow: Publishing house of Moscow State University: INFRA - M.

Strumilin, S.G. (1924). The economic value of public education. Moscow: Economic life.

Strumilin, S.G. (1962). The effectiveness of education in the USSR. Economic newspaper, 14, 28-30.

Toffler, A. (1990). Powershift. New York, Bantam Books.

Vernadsky, V.I. (1991). Scientific thought as a planetary phenomenon. Kyiv: Science.

Zhamin, V.A., Egiazaryan, G.A. (1968). The efficiency of skilled labor. Moscow: Pravo-Ko. 
Received: 31 August 2021 | Accepted: 20 November 2021 | Published: 18 January 2022

(c) (1)

This is an Open Access article distributed under the terms of the Creative Commons Attribution License, which permits unrestricted use, distribution, and reproduction in any medium, provided the original work is properly cited. 